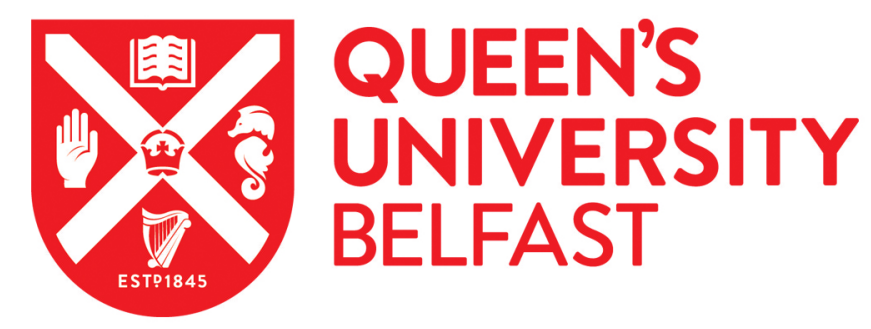

\title{
Dissidents with an innovation cause? Non-institutionalized actors ' online social knowledge sharing, solution-finding tensions and technology management innovation
}

De Kervenoael, R., Bisson, C., \& Palmer, M. (2015). Dissidents with an innovation cause? Non-institutionalized actors ' online social knowledge sharing, solution-finding tensions and technology management innovation. Information Technology and People, 28(3), 653-676. https://doi.org/10.1108/lTP-04-2014-0067

Published in:

Information Technology and People

Document Version:

Early version, also known as pre-print

Queen's University Belfast - Research Portal:

Link to publication record in Queen's University Belfast Research Portal

Publisher rights

Copyright 2015 Emerald.

\section{General rights}

Copyright for the publications made accessible via the Queen's University Belfast Research Portal is retained by the author(s) and / or other copyright owners and it is a condition of accessing these publications that users recognise and abide by the legal requirements associated with these rights.

Take down policy

The Research Portal is Queen's institutional repository that provides access to Queen's research output. Every effort has been made to ensure that content in the Research Portal does not infringe any person's rights, or applicable UK laws. If you discover content in the

Research Portal that you believe breaches copyright or violates any law, please contact openaccess@qub.ac.uk. 


\section{Dissidents with an innovation cause? Non-institutionalized actors' online social knowledge sharing, solution-finding tensions and technology management innovation}

\section{Introduction}

Attitude change has long been regarded as an important factor enabling technology management innovation (Reychav and Weisberg, 2009; Birkinshaw et al., 2008; Fisher, 2012). Birkinshaw et al. (2008, p. 829) define management innovation as "the generation and implementation of management practices, process, structure, or techniques that is new to the state of the art and is intended to further organizational goals". Studies point to various actors' participation in enabling technology management innovation including, existing management (Birkinshaw et al. 2008), existing consumers (Brockman et al, 2012; Zablah et al, 2012; Lafferty and Hult, 1999) and existing employees (Wang et al, 2011).

One limitation of this body of research, however, is its focus on technology innovation from a management-driven way as it unfolds within 'the firm', rather than the ways that such practices span social, temporal and organizational boundaries visà-vis technology artefacts, agendas and capabilities (Gazzoli et al, 2013). Much less studied is the role of peripheral non-institutionalized actors in enabling technology management innovation such as in web design services (Bijker and Law, 1997; Nov et al., 2012; Galvin, et al., 2005). Yet, the role of non-institutionalized actors is important, not least because such actors engage in boundary field work, competing and challenging the existing dominant institutional logics. An example of these competing logics is the way in which an institutionalized corporate agenda is associated with the economic logic of exchange and cost efficiency. While on the other side, an non-institutionalized web designer is associated with the logic of design 
for design's sake. This is reflected in web designers' desire to do work considered 'good' by their peers (McLeod et al., 2011). We argue that when the firm places a relatively higher emphasis on conformity, for example, via 'a brief' or 'a contract', it unintentionally regulates the rate of non-institutionalized deviance practice. Here, non-institutionalized deviance refers to the violation of the normative expectations of the social context (Cohen, 1999). Deviations, intended and unintended, recognized or not, authorized or not, prescribe and proscribe particular forms of use that are hard to pre-determine. However, in the pursuit of solution-finding paths, non-institutionalized actors' deviance produces the tensions within the social structures.

The present study attempts to redress this imbalance in the literature by undertaking a qualitative exploration of the nature and role of dissident noninstitutionalized actors' practice for enabling technology management innovation. For the purposes of this study, we investigate the role of outsourced web designers and rapid application software developers as the dissident non-institutionalized actors. Specifically, we frame our analysis on the peripherally deviant work and the ways that such dissident non-institutionalized actors deviate from their clients (understood as the firm) original contracted objectives. These dissident non-institutionalized actors are identified by, and subject to, several characteristics including; (i) considerable labor market flexibility and consultative expertise capability, (ii) disembeddedness resulting from occupying a techno-nomad role and 'docking stations' remits, (iii) accelerated obsolescence of skills from technological advancement, (iv) boundaryspanning work across multiple social, organizational and temporal spaces and (v) working remotely, occupying the 'places on the margins'. These characteristics are also balanced by their depository of online cultural capital and abilities to learn, adapt and share (Tymon and Stumpf, 2003). 
The overall aim of this paper is to explore the role of knowledge sharing practice amongst dissident non-institutionalized actors in the practice of technology management innovation. Specifically, the research has two objectives. First to explore role of social knowledge sharing by dissident non-institutionalized actors in the coproduction of web designs. Second, to explore the tensions arising from deviant practice with their clients (understood as the firm) original contracted objectives. The primary focus of the paper is therefore the social knowledge sharing by outsourced web designers and RAD developers and how the nature of that practice enables technology management innovation.

In a recent study, Ansari and Phillips (2011) note that management innovation in Information Systems has yet to theoretically integrate the role of a range of actors in creating, developing, encouraging and legitimizing technology management innovation practices (see also Galvin et al, 2005; Castells, 2001; Dacin et al 2002). To address this gap in our understanding, many calls have been made for the boundaries and nuances of technology management innovation theory to be conceptually broadened. This requires research to account for and make sense of the peripheral, non-institutionalized actors who are physically or socially remote, yet socially an integral part of the community of actors in technology management innovation (Coleman, 1988; Baker, 1990). Nowhere is this social interaction and knowledge sharing practice more evident than in the evolution from Web 1.0 to Web 2.0 (including the related associated technologies: social network, blogs, wikis, video/photo sharing, e-crm, RSS, and virtual online 3D worlds etc), and its enabling of connectivity between users and firms.

Conceptualising and bringing in the role of non-institutionalized actors (e.g. outsourced web-designers) in the production of web designs can be understood as a 
dynamic and socially interactive and knowledge sharing activity. Increasingly, this social interaction is considered to be a social capital resource that actors develop from specific social structures and maximize towards the achievement of certain goals. According to Bourdieu and Wacquant (1992, p. 119), social capital represents "the sum of the resources, actual and virtual, that are accrue to an individual or a group by virtue of possessing a durable network of more or less institutionalized relationships of mutual acquaintance and recognition". Social capital theory emphasizes the value of social networks, the bonding ...[of potentially]... similar people and bridging between diverse people, with norms of reciprocity reflecting the changing nature of IT mediated service encounters (Dekker and Uslaner, 2001; Burt, 1997; Compeau et al, 1999; Bessant et al, 2003).

The theorization of the social capital boundaries between what happens inside and outside firms, in what are often knowledge intensive firms, is mostly taken for granted and often does not reflect changes arising from the shift from traditional hightouch and low-tech (e.g, shift from simple brochures into sophisticated, interactive multimedia entertainment experiences at low cost) to high-tech and high-touch (e.g virtual store and sales avatars) (Froehle and Roth, 2004). Consequently, Reychav and Weisberg (2000, p. 354) posit that, "since most firms have access to the same technology, such generic technologies are unlikely to explain variance in customer service performance across competing firms". Other studies have argued along similar lines (Chu and Chan, 2009, Denegri-Knott, 2006, Lusch, et al., 2007; Wu, 2008). In this paper we advance the argument that social interaction and specifically knowledge sharing practices between various actors may account for some of the variance in process performance. 
Significant in all of this activity is the way in which the social participation and interaction of non-institutionalized actors take place (Ansari and Phillips, 2011). Ansari and Phillips' (2011) study demonstrates that non-institutionalized actors actively challenge an established institutionalized practice. This, in turn, may create tensions between the various actors, thus enabling technology management innovation. Here, tension is defined by Poster (1992, p. 94) as "the way individuals and groups practice a strategy of appropriation in response to structures of domination." From this tension perspective, Johnson, et al., (2007, p. 322) suggest that "technical communicators influence technology use and the transfer of knowledge about these technologies". Deviating from the original contract objectives in fulfilling the actual web design, challenges the social conditions in which the various actors operate and interact. Social interaction and knowledge sharing capabilities can therefore create the conditions for tensions between: the status quo and the new cultural practices (Zakaria et al, 2003; Berthon et al, 2012); the existing corporate goals and the technological capabilities in practice (Tams, 2013); in-house propriety knowledge and outsourced bespoke technological capabilities (Yu and Hang, 2010); and between institutionalized actors (e.g. managers of the firm) and noninstitutionalized actors (e.g. outsourced web-designers) over existing contractual agrements (Curran et al, 2003; Müller and Nielsen, 2013). The social learning behavior of individuals may fundamentally reconfigure the production of use and exchange value previously considered an internal practice or process of the firm (Daniel, 2009; Robert et al, 2008; Prahalad and Venkat, 2003; Ratten, 2009). Therefore, dynamic and interactive platforms on multiple media may disrupt existing paths in the search for solutions for consumers' needs and wants, while also fulfilling 
and/or undermining the cost-reduction and efficiency objective pressures of the firm within increasingly complex service encounters (Cova, et al., 2007).

From our research we can identify two theoretical contributions. First, with a few exceptions, researchers in online services and web development literature are only now beginning to examine practices by non-institutionalized actors which shape management innovation (Curran et al, 2003; Müller and Nielsen, 2013). Our study extends this work and shows the nature of the tensions in the social knowledge sharing practices between existing institutionalized actors and non-institutionalized actors. Second, while a heavy emphasis is placed on technology-led strategy planning in most prior studies, comparatively little is known about how tensions emanating from the unplanned and emergent online knowledge sharing strategies which enable 'normal' and 'deviant' behavioral practices by dissident actors (Walker and Johnson, 2006). Studying the practice of dissident non-institutionalized actors' deviance from their clients' (understood as the firm) original contracted objectives can provide insights into the nature of technology innovation management.

The remainder of this paper is organized as follows. Section two defines sources of online social knowledge and provides the theoretical background using social capital theory. We then propose a framework that combines social capital theory with a justification for the deviant practices of web designers. This framework in turn sheds light on new potential sources of IT service management innovation. We then outline the methodology along with the presentation and discussion of findings. The paper concludes with managerial implications for management innovation.

\section{Theoretical background}

Social capital theory and online social knowledge 
Online social knowledge is increasingly described as the main building block in IT service research that decodes and encodes digital information and intellectual capital (Orlikowski, 2010; Tohidinia and Mosakhani, 2010). According to social capital theory, social knowledge is defined as 'a resource that actors derive from specific social structures and then use to pursue their interests; it is created by changes in the relationship among actors' (Baker, 1990, p. 619). The paper, therefore, redefines the critical moments of interaction and sharing between firms and customers in IT service encounters. For a recent review on the dimensions of social capital see Wickramasinghe and Weliwitigoda (2011). Scholars find that social capital online is characterized as brokerage opportunities within a network (Burt, 1992).

Reflecting these arguments, we consider social knowledge to be the sum of web experiences including: (i) communication practices encouraging the discussion of norms and beliefs (e.g. politics and religion) during IT mediated service encounters, (ii) knowledge association with lifestyle symbols (e.g. gender, posture, etiquette) during the exchange with front line employees (behind technologies in our case), and (iii) environmental, personal/professional status together with social knowledge reference points demonstrating the importance of interpersonal aspects in determining IT mediated service experiences (Brown et al., 2007; Bitner et al, 2000). Current attitudinal research on online knowledge management examines: (i) the importance of Word of Mouth (WOM) (Brown et al, 2007), (ii) the effect of social identification on organizational knowledge sharing (Zhou, 2011; Wickramasinghe and Weliwitigoda, 2011), (iii) the application of new and existing knowledge management in key business processes (Dotsika and Patrick, 2013; Ndlela and du Toit, 2001), (iv) resistance to technological innovations and service failure/recovery (Lin et al, 2007; Yen et al, 2004), (v) software process improvement (SPI) (Müller and Nielsen, 2013), 
(vi) value sensitive design (VSD) (Johri and Nair, 2011), (vii) usability (Clemmensen and Roese, 2010), and (viii) investments in information technology to facilitate efficient knowledge management (Kim and Lee, 2010). Much less considered in all of this research activity is the way in which social capital practice creates cultures of deviance, where knowledge workers diverge from institutional norms, standards and contractual requests.

\section{Diverging from institutional norms: the role of dissident actors}

Studies in the institutional field show that actors converge to the institutional forces and cultures (DiMaggio, 1998). DiMaggio (1998) defines culture as "an interdependent set of representations or constraints that influence action in a given domain [...] fragmented across groups and inconsistent across its manifestation" (DiMaggio, 1998, p. 264-277). Furthermore, Swidler (1986, p. 280) demonstrates that "culture provides the materials from which individuals and groups construct strategies of action”. For a complete review of culture used in IS research see Tams, (2013). Thus, culture emerges from various combinations of resources (e.g. norms, values, beliefs and technology) across different institutional settings.

Not all of the actors become institutionalized, however. Consumers, for example, can employ resources from several registers (field level resources) and repertoires (actor level resources) like abstract dimensions such as size, diversity, stability, complementarities, similarities, and detailed themes such as norms, values, frames, ritual, and humor (Martin, 2002). Detecting these dynamics can be facilitated by understanding the social knowledge sharing strategies deployed by actors that utilize deviant practices (Levi, 2011). In addition, the notion of the 'institutional entrepreneur' often refers to the individuals that re-shape, re-frame, and help in the 
establishment of new practices beyond institutionalized behaviors (Lounsbury and Crumley, 2007). Within this literature, the concept of the 'institutional entrepreneur' has been criticized for attenuating the strategic nature of, and focusing exclusively on, the role of 'heroes' and 'mavericks' in innovation practice, rather than the wider array of third party non-institutionalized actors. Ansari and Phillips' (2011) study shows how individual dissent or deviance can actively challenge an established policy, institution and institutionalized practice. These dissident non-institutionalized actors thus become critical for understanding technology innovation management.

\section{Dissident actors and technology innovation management}

From the perspective of the dissident non-institutionalized actors, the focus of interest is not on their technical capabilities, but the knowledge sharing interactions of web-designers through deviance from the contractual agreement to improve IT mediated service encounters. The institutional conditions provide dissident noninstitutionalized actors more social scope and opportunity to deviate. Ram and Sheth (1989, p. 6) characterize deviance as "the resistance offered by [an individual] ... to an innovation, either because it poses potential changes from the satisfactory status quo or because it conflicts with their belief structure". This deviance can cause tension. Collison (1994, p. 49) suggests that tension arises from attempts to "challenge, disrupt or invert prevailing assumptions, discourses and power relations". Building on this conceptual definition, Fleming and Spicer (2008, p. 29) outline four key practices of deviance including: refusal, voice, escape and creation.

"Refusal overtly blocks the effects of power by undermining the flow of domination. Voice demands that those in control change particular aspects of power relations to favor those being affected by them. Escape reflects 
processes of mental disengagement from the workplace: cynicism, skepticism and dis-identification. Creation refers to the way that alternative identities and discursive systems of representation emerge within domination [..] (Tension represents) a manifestation of deepseated struggle that springs forth from collective communicative conflicts around certain issues" (Fleming and Spicer, 2008, p. 305).

For Penaloza and Price (1993, p. 125), tension is conceptualized as "trouble with the sudden intrusion, the unanticipated agency of a consuming subject which inexplicitly reverses the marketer's gaze and contests the place and authority of the marketing position". Consequently, analyzing tension from a social capital framework point of view theoretically enriches the way to understand how "individuals and groups practice a strategy of appropriation in response to structures of domination" (Poster, 1992, p. 94). The conceptual area of tension is comparatively less developed and requires more research attention (Toral, 2013).

A review of the literature highlights some important issues. First, online social knowledge sharing is evolving within the dynamic environment of IT mediated service encounters (Chu and Chan, 2009), often outside firm-centric boundaries, and through non-institutionalized networks. Second, the role of technology innovation management as a form of deviance by dissident voices in social knowledge sharing practice has received little academic attention. Finally, most, if not all, conceptions of tension are seen as negative, yet tensions within online social knowledge sharing may create paths for enhancing IT service experience.

\section{Research methodology}


In order to better understand the research objective a series of exploratory in depth-interviews was undertaken since there is little, if any, research into the nature and role of dissident non-institutionalized actors for enabling technology management innovation. Although the survey questionnaire is used in several IS and technology acceptance models (Rogers, 1995; Teo, et al., 2007), online social knowledge's early stage of development limits the availability of consistent scales and metrics. Rather, our research approach follows Geertz' (1973) design which aims to produce 'thick descriptions' of the phenomenon under study.

\section{Data collection procedure}

During 2010 twenty-one semi-structured interviews were undertaken via Skype. This data collection coincided with the growth of the HTML 5 programming language, Ipad 2, iPhone 4, the Android operating system, mobile apps, all of which were significant for all enhancing social media and the subsequent social knowledge sharing revolution. A convenience sampling addressed the research question (Neuman, 2006). Respondents were recruited from an advertisement on Coroflot (www.coroflot.com). Selection criteria were: (i) US web design employment, (ii) range of firm experiences (see type of website designed in Table 1 as well as demographics (full anonymity followed our institution's ethical guidelines), (iii) primary occupation as website designer. Most importantly, in the last two columns, the type of website developed by our sample and the array of respondents' most influential online source of social knowledge, allows for a greater grounding of the discussion.

\section{Data analysis procedure}


Despite the sampling constraints of voluntary participation, an adequate mix exists of gender, age, cross ethnic social backgrounds and employment lengths (average twelve years of experience) are all present in the sample. The themes investigated are derived from the above literature including : (i) definitions of key terms (web designer, online social knowledge, management innovation, network, value creation, external agents, tension) and roles, (ii) the meaning and purpose of website design in relation to engagement with online social knowledge sharing within IT mediated services encounters (Baker, 1990; Orlikoweski, 2000, Kim and Lee, 2010; Johri and Nair, 2011), and (iii) identification of 'deviance' from the original contract enabling tension (Holt, 2002; Sharma and Baoku, 2013).

In addition, a laddering method (starting by querying the meaning of the obvious) was utilized, which probed for the differences with and without social knowledge sharing activities. Such an approach accommodates the observation that individual respondents were already abrogating certain choices and behaviors (consciously or unconsciously). In this way, analyzing unsolicited accounts and routine experiences with that 'framework analysis' followed Jones' (2000) research approach. Framework analysis is particularly appropriate for research that has specific themes to investigate, a limited time frame, a pre-designed sample (e.g. professional participants) and a priori issues (e.g. organizational) that need particular attention (Ritchie and Spencer, 1994). In line with this approach we began by reading the interviews' transcripts and familiarized ourselves with the data. Second, the key issues in the data were identified and matched with more abstract concepts in the literature in order to construct a final thematic framework for analysis (Ritchie and Spencer 1994). Third, the indexing process in which the thematic framework was systematically applied to the data was initiated. Classification of the data was 
supported by Nvivo9. Finally, a picture of the data as a whole was constructed and schematically mapped. Using the general categories and subcategories assigned to the data, we interpreted the data as a whole and visualized organically emerging constellations. Re-reading the data and re-working on the categories was a process of agreement amongst the authors (Goodwin and Goodwin 1984; Punch 1998; Silverman 1993).

[Insert about here Table 1]

\section{Findings}

The analysis of the interview data highlights three main meta-categories in online social knowledge sharing between web designers and RAD software engineers (i.e. dissident non-institutionalized actors) and the client firms. The findings are therefore organized under three headings: functional recognition, ideological reflection, and market cultural compatibility actions (see Table 2 for a selected example of coding).

\section{Functional recognition}

The first tension theme that emerged from our analysis is termed functional recognition of online social knowledge sharing. Online social knowledge sharing was highlighted by all our respondents as governed by functional codes and technical bureaucracies. All reported that day-to-day practices (including technical standards, official formats, approved content and language) dictates and exerts considerable power over when, where, and how online social knowledge sharing contributed to responding to customer needs within IT service encounters. Functional transgression - understood as a deviation from basic mechanical social knowledge 
sharing (e.g. a 'like' button) —was described as a means of voicing (18 out of 21), exploring (6 out of 21), and debating (21 out of 21) potential evolutions and creating the conditions for dislocation and differentiation. One designer explained that imperative:

\begin{abstract}
"Today, you should probably stick with the best practices and what your contract says I believe ...but I would try to do something that's different because if you do not try to do something different, why do it in the first place? There is no value in reproducing the same knowledge ... and not attempting to capture new trends" JOHN
\end{abstract}

Online social knowledge sharing as dislocation was perceived as already happening (19 out of 21). Wikileaks and Wikipedia were given as examples of knowledge repositories that force firms to re-think their strategies towards free knowledge, transparency and multiple authorship power models. In that sense, online social knowledge sharing was identified in voicing opposed perspectives, encouraging politically incorrect and non-self-censured communication to humanize IT service encounters. Yet, this non-official knowledge was also clearly identified as colliding with traditional IT service management innovation processes, roles and power, a phenomenon rarely acknowledged in the literature (18 out of 21). One designer argued that:

\footnotetext{
"the value of online social knowledge sharing rests in the balance of social ingredients included in web design that emerge from the marketing departments of clients, the final users and us as translators. " $B O B$
} 
Sources of social knowledge sharing are thus identified as resulting from deviance against (i) traditional top down power and control sources (16 out of 21) and (ii) the misguided belief that processes to satisfy customers' needs mainly emerge from within clients' strategies (after listening to the market: i.e. market research and other institutionalized agents such as consultants) (11 out of 21). An experienced designer explained that:

\begin{abstract}
"In a virtual environment, all can be upside down, you are who you want and you can be as creative as you want. This disturbs traditional management strategies for clients, they have less control. Skype bypasses managerial control and cloud computing is coming and allows sharing, transparency and very large participation. They should be seen as opportunities to put in place structures that allows greater access to social knowledge sharing to generate innovation" ACHILLE
\end{abstract}

Consequently, the dissidents' practical styles of social knowledge sharing were presented as deeply anchored in their specific individual cultures (17 out of 21$)$. For example the de-localization of technical tasks to low cost countries was underlined as 'a double hedge and risky strategy'. An expatriate designer explained that:

“...cultural understanding has to do with your upbringing and exposure to a diversified environment...... Then innovation can emerge combining personal identity available technological tools and clients' ideas. This is what you lose when you outsource design outside the local or domestic area and consider design as technical, finished, and immutable." BARRACK 
According to the majority of respondents, online social knowledge sharing emerges from tension in areas aiming to foster local or targeted audiences' trust (14 out of 21). Such social knowledge sharing was perceived by the respondents as dependent on dissidents' overall social knowledge background including specifically their education. As a practical example given in engineering schools, very limited skills were said to be taught about topics often omitted from the curriculum-- how to cultivate and present social knowledge content regarding gender, fads, and fashions. The idea of IT service encounter and experience was also streamlined mainly to the two core concepts of usability and convenience. Two contrary views emerged from the sample of respondents. One view was summarized as follows:

“...it is too difficult to keep in touch with the world's social knowledge. I am an engineer; I have learned to keep in touch with new technologies only... [...]..Clients want users to act, to buy. They want to make it really easy for them not to think about the website. And they [clients] do not want to know what they [designers] think; this may lead to questions they do not want to answer. ALBERT

The other view was outlined by another designer:

"I am a very big believer in what is called emotional intelligence but that usually comes from users, and clients find it hard to capture such value .... In every profession, you always have like ten percent of people doing amazing things and then ninety percent regular things. Service innovation consists in the development of instruments that allow such social knowledge to be made available for all" BRUCE 
For most respondents (16 out of 21), a dis-identification process seems to be at work whereby the classic, basic online social knowledge frameworks - (Facebook, Twitter, blogs, RSS widgets icons) - are repeatedly displayed as a reflection of the lack of involvement and willingness towards further development that encourages integrated interdependent strategies. These positions are found to comply with the vision conventions of most traditional firms:

"... what you are going to see (more) is people designing for niche cyber culture around a group of self selected experts interested in specific areas. As it takes a lot of specific social knowledge to really understand emerging online social culture, they can derive a premium from that. But most clients, especially smaller firms, they want the basic, short term sales which are the only objective” THOR

In this ongoing debate, at times deviance was described by all respondents as messy and problematic to implement for such reasons as: (i) contractual/legal compliance and (ii) the fact that online social knowledge sharing processes involve a long term approach with much updating. A designer explained that:

“... creating a space that monitors many actors and collects user-led social ideas... to create online social knowledge sharing would increase the cost by $15-20 \%$. BRUCE

Therefore, we propose that significant interaction exists between the voicing of web designers' functional recognition of the ex/inclusion of online social knowledge and the source of IT management innovation within service encounters. 


\section{Ideological reflection}

Another important theme to emerge from the analysis is termed ideological reflection of online social knowledge sharing. Most actors described online social knowledge sharing as existing within a powerful managerial technological cultural meaning system whereby a specific power source (for example, the client's marketing department) constrained the social richness of other agents' cultures (15 out of 21). The ideologies attached to this work produced organisational tensions relating to disclosure and change at the client level, despite lengthy rhetoric about firms' marketorientation. A lack of processes and structures during IT service encounters to record and leverage intellectual capital shared online was noted (10 out of 21). Just under half of the sample described deviances aimed at opening up traditional managerial systems and conventions as sources of innovation that provide free agents such as designers with a sense of agency and individual purpose (10 out of 21). One designer explained that:

"I think that a lot of companies are self-centered (especially in America) and they don't really think about how online social knowledge sharing is going to precipitate innovation and affect power among people. But some firms are changing and leading the way on platforms such as Facebook. Ideologically, it seems harder for the firm as a whole than individuals within, as they have to decentralize their systems and are not sure about who is going to benefit and get the power" KAREEN

It was pointed out by most respondents that clients had a strong animosity against unregulated knowledge (often oral/video) and cultural signals that do not fit current corporate values and operations, stripping away any sense of designers' 
agency - that is to say, their ability to act (16 out of 21 ). Processes to engage and respond to communities as a whole rather than individual feedback on social media were described as mostly inexistent. The majority of clients were depicted as having a paternalistic approach to online social knowledge sharing in which they 'know better' than web designers or customers about IT service experience. Variance was expressed between sites for e-commerce where little agency is authorized and sites for entertainment or for NGOs where agency is often even encouraged (8 out of 21).

Reasons advanced for such ideologically motivated negative attitudes to online social knowledge sharing were expressed on a continuum as: (i) dispositional tension (i.e. not now), (ii) cognitive rigidity (i.e. do not want to think about changes), (iii) preference for low level stimulation rather than novelty and (iv) lack of resilience (i.e. having to justify choices to the client). A designer illustrated such claims as follows:

"I think that these clients have convinced themselves or that their perceptions have been molded around the idea that everyone who looks at web sites is either in the USA or adaptable to what we in the USA are looking at and understand. They see US citizens as a homogenous group only. With that many Hispanics! (Laugh). Hence they do not see any value in developing or adapting online social knowledge. I doubt there is little reward in fighting the current” $B O B$

Likewise, ideological deviance by dissident web designers from clients' knowledge domination was said to be currently only occasionally leading to the innovation (6 out of 21). One example was the clients who want to try to understand coding. Explaining HTML, CSS and Java script coding principles to clients was said to lower 
misunderstanding and open doors for possibilities through co-creation and better understanding of the basic practices of online social knowledge sharing. The process was described as a necessary pre-task that aligns language perspective and understanding of technology impact on service encounters early in any project. It was also underlined as innovative practices removing fear and cynical hideout tactics by both parties. An enthusiastic designer illustrates the debate:

“...... innovation lies in the mindfulness and the appreciation of the technical processes rather than the fear of the black box. So I think value is about capturing diverse audiences' perception ... leverage of technical power should also come from various sources... still even technical creativity is often crunched before birth by over detailed contractual rules". ACHILLE

Apart from the dissident actors distancing themselves from any particular social knowledge community, ideological deviance also led to their perception of two main groups/camps. On the one hand, one group was described as routine-seeking in which postponement of online social knowledge sharing was commonly identified ( 8 out of 21). This sub-group, portrayed inertia as a comfortable status quo, rewarded by clients (mainly smaller firms) that often did not understand online social knowledge sharing in relation to IT service experiences. Routine-seeking mechanisms and intolerance to periods of adjustment were also perceived as key drivers. In this group, respondents were of the opinion that this type of designers favored habit over the inconveniences of change (i.e. resisting micro-management and questioning). Accordingly, winning the next contract was described as more important than online social knowledge sharing inclusion to improve IT service experiences. 
On the other hand, a second group (13 out of 21) comprised dissidents framed the argument in historical rhetoric terms - experience-driven - who perceived themselves as 'grown ups' in the social media revolution. Those dissident web designers were opposed to the commoditization of the online environment. They characterized themselves as more comfortable about expressing conflicting demands that lead to engagement with online social knowledge sharing as sources of IT service management innovation. A dissident actor argued that:

\footnotetext{
"A lot of decision makers have grown up without this media and they simply have a huge disconnect in term of organizational power relationship. .....I present to them very good ideas and potential solutions and they won't go after that just because they don't understand it. They also don't need to include online social knowledge sharing for the moment because nobody big does it". LOUIS
}

These divergent groups are also reflected in the literature on power, organizational change and regarding ethical concerns (Russel and Russel, 2006; Pile and Keith, 1997). This finding leads to the second proposition in which dissident actors openly refusing online knowledge commoditization hold a more favorable view of online social knowledge sharing as a source of engagement processes within IT service management innovation.

\section{Market cultural compatibility action}

The final meta-theme to emerge from the analysis related to the market cultural compatibility action of online social knowledge sharing. Several respondents pointed to the constraints of traditional market power and contractual legal framework 
in prescribing behaviours to control business interests. Despite the emphasis on open strategies, innovations and cultures, the online channel regularly contests such claims:

"There will be privacy and minority issues especially in the USA if you personalize more the content. They do not see it as value-added but as possible litigation." JENNY

Political correctness within online social knowledge sharing was described as requiring re-definition and extension beyond government and industry codes (15 out of 21). It was found that new online social knowledge sharing standards were emerging, but these new standards were neither driven by firms nor policy or legislation. In addition, free service websites (which run contrary to traditional market forces) were regarded as examples of true online social knowledge sharing. A dissident commented about these issues:

"The world is getting so big, the media landscape is getting so huge with so many sub-groups and clans such as game 'geeks' that in order to really connect with that audience you really need to tailor your content and your web site to that audience knowledge." WAY

Six respondents proposed a new job title 'customer knowledge experience advocates' to identify the interdependence among agents and as a potential source of online social knowledge sharing. They advised a blog maven fulfill these positions. Rather than a full time employee as in conventional firms, an unlimited number of experts could be accessed. Finally, the findings reveal a curvilinear-type process at work. Timing for actions is important when leveraging deviance from contractual obligations as a source of online social knowledge sharing. Deviance enacted too 
early in the web design at or during the contractual stage was identified as negative, resulting in team disintegration and distrust. Moreover, at a point in the advanced design process, acting on deviance was also synonymous with work destruction. Consequently, web designers' resisting the traditional market force's status quo (contractual agreement) and deploying timely strategies enabled them to escape and hold a more favorable evaluation of online social knowledge sharing as a source of service management innovation.

\section{Discussion}

In this paper, our first objective was to explore the role of social knowledge sharing by non-institutionalized actors (e.g. outsourced web-designers) in the production of web designs. Despite the World Wide Web's existence for more than two decades, interview data suggest that the leverage of online social knowledge sharing to foster IT management innovation is still emerging (Berthon et al. 2012) The non-institutionalized actors' perceptions revolve around functional recognition, ideological reflection, and market cultural compatibility as actions that enable technology innovation management. Dissent is evident in each category. Through the analysis of interview data three advances in understanding online social knowledge sharing towards technology innovation management emerge. The findings expand the understanding of the sources of online social knowledge sharing also echoed in Tohidinia and Mosakhani (2010) as well as the relationship between practice and deviance (Pile and Keith, 1997). Second, the findings demonstrate the potential effectiveness of positive deviance via dissident non-institutionalized actors as a way of addressing knowledge misalignment in IT management (De Kervenoael, et al., 
2013). Finally, a crucial point is identified regarding the fact that the process is not to be merely considered to be a technical practice.

The existence of deviance illustrates that tension is not uniformly perceived nor accepted by all dissidents and that acceptance of online social knowledge sharing strategies may not be immediate. Overall, most respondents sought new rules and processes to develop and include online social knowledge as a legitimate and beneficial differentiation of assets within service encounters. Most dissidents clearly developed an emotional attachment to online social knowledge through their passionate efforts to share with their clients (Walker and Johnson, 2006). That effort places renewed importance on and seeks to analyze the independent vs. interdependent relationships between (a) clients/marketers, (b) customers and (c) noninstitutionalized third party providers in service encounters.

\section{Theoretical contributions}

This research contributes to the IT and management literature in several ways: first, we move beyond a macro approach -external vs. internal agent of changetowards the meso-level represented by boundary-spanning dissident actors. The dissidents' roles in capturing online social knowledge during service encounters embody more subtle forms and engagement in far broader issues than do the more proximate position of management consultants (Zhou, 2011; Wu, 2008). Second, our framework helps sensitize the literature in terms of deepening our understanding of dissent. Specifically how dissident non-institutionalized actors bring about social action, interactions and interdependencies among agents (De Kervenoael, et al., 2014). Yet, we note that the strategic boundaries between the firms as clients and 
dissidents are ambiguous and positively contested. This essential step will familiarize online social knowledge sharing via a dispersed set of influence peddlers. In this regard, our data suggest that firms will need to learn further to gather and assemble multi-format online social knowledge and how to re-deploy that knowledge towards sustainable innovation (Harris, 2000; Levi, 2011).

Furthermore, the analysis contributes three advancements in the literature on understanding IT innovation management and strategy. First, by focusing on the processes that lead to the creation of new practices as in the case of knowledge sharing, we expand the understanding of the sources of IT management innovation as well as the relationship between practice and deviance (Toral, 2013). This paper demonstrates the positive nature of deviance and the associated tensions (refusal, voicing, escape, and creation) for enabling technology management innovation (Fleming and Spicer, 2008). Dissident actors tear at the institutionalized fabric which is seen to constrain technology innovation management. Therefore, positive tension as a way to addressing the shared knowledge misalignment is found to be important in its own right. A crucial point is that the process is identified not to be merely technical; non-institutionalized actors and clients must perform ritual and symbolic activities in order to gain membership in the cyber-community' culture. Analysis of tensions leads to the identification of two sub-groups. The existence of these subgroups illustrates that tension is not uniformly accepted and that acceptance of discursive power strategies via the unpacking of tension is not immediate. Actors in the second group clearly developed an emotional attachment to their design through their passionate efforts to share with their clients. That effort places renewed importance on, and seeks to analyze, the independent vs. interdependent relationships 
and roles between clients/marketers and non-institutionalized meso-level actors within IT management.

Second, the analysis reveals that through three phases of tension -functional, ideological and time related tension- there are genuine, novel sources of IT management innovation to be leveraged. The functional practices are associated with the voicing of individual tensions underpinned by the more fundamental issue of inactivity-interactivity and the systemic silencing of non-institutionalized actors and issues by technology (Flemming and Spicer, 2008). Practitioners' ideological tensions as a refusal of the status-quo involves shaping questions around the 'doing' and 'how' this occurs.

Third, the timing of deviance involves balancing market forces linked to the competing trade-off of tensions between the vested interests of finding solutions (e.g. where loyalty lies) with profit (Spicer and Böhm, 2007). Tension explicitly allows for the emergence of a plurality of interests, values, loyalties, histories, preferences and prejudices to emerge (Penaloza and Price, 1993). Our analysis finds that noninstitutionalized actors are the source of novel consumption practices associated for example with art, luxury, and lifestyle consumption. Furthermore, in showing how tension is exercised in practice, the findings point to a need for status recognition within the profession.

\section{Managerial implications}

The implications for practice are underlined in the three propositions. Our research confirms the finding that deviance is 'often ambivalent, subversive and complicit in the very same moment' (Fleming and Spicer, 2007, p. 307). Deviance explicitly allows the emergence of a plurality of online social knowledge, values, 
loyalties, histories, preferences, and prejudices to emerge and to be voiced within service encounters. Equally important, it enables technology innovation management. Managers are encouraged to conduct more testing and dynamic designs. These solution paths are about re-defining technology management in our personal lives when non-strategic, non-core actors are authorized and encouraged to shape and change the expectations in our professional lives. It is often noted that when Steve Jobs introduced new products he used such terms as 'delightful' and 'amazing'; however, within management innovation in IS such a vocabulary is almost nonexistent nowadays (Chia and Holt, 2006). We secondly traced key turning points in enacting/resisting the inclusion of shared knowledge. By examining these points, we have contributed to the management framework which attempts to reconcile technology and culture (Snow, 1993) by conveying both an image of technical conformity and social creativity. This will help managers to better understand the ever-broadening social media ecosystem (e.g. global vs. national vs. local social media platform or smartphone vs. laptop) and provide a means for shaping and influencing dissidents and associated discourses.

\section{Limitation and further research}

As noted by Gazolly et al. (2012), it is also essential to maximize sample size and diversity (e.g. several industries, across several geographies and cultures); although at the same time, scholars should also recognize the rich insights that data from smaller qualitative samples provide for empirical research and theory development. We believe that our sample, with an average of over 12 years' experience, mixed gender as well as nationality, all working within the US ecosystem, 
provides some confidence that the findings obtained in this paper are indicative of substantive relationships between the themes.

The findings of this paper provide several directions and opportunities for future research including: (i) the need to explore how deviance can be negotiated at times of change/crisis beyond the typical depiction in the literature of 'winners' and 'losers'; (ii) online social knowledge sharing practices displayed by all agents which will need to be investigated under the specific context of market creation rather than the traditional market driving strategies.

\section{References}

Ansari, S., and Phillips, N. (2011), "Text me! New consumer practices and change in organizational fields", Organization Science, Vol. 22 No. 6, pp. 1579-1599.

Baker, W. (1990), "Market networks and corporate behavior", American Journal of Sociology, Vol.96 No.3, pp.589-625.

Berthon, P. R., Pitt, L. F., Pitt, Plangger, K. and Shapiro, D. (2012), "Marketing meets Web 2.0, social media and creative consumers: implications for international marketing strategy", Business Horizons, Vol. 55 No.3, pp. 261-271.

Bessant, J., Kaplinsky, R., and Lamming, R. (2003), "Putting supply chain learning into practice", International Journal of Operations and Production Management, Vol.23 No.2, pp.167-184.

Bijker, W., and Law. J. (1997), Shaping technology/ building society, MIT Press, Cambridge, MA.

Birkinshaw, J., Hamel, G and Mo, M.J. (2008),"Management innovation". Academy of Management Review”, Vol.33 No.4, pp.825-845. 
Bitner, M. J., Brown, S. and Meuter, M. (2000), “Technology infusion in service encounters”, Journal of the Academy of Marketing Science, Vol.28 No.1, pp.138-149.

Bourdieu, P. and Wacquant, L. J. D. (1992), An invitation to reflexive sociology, University of Chicago Press, Chicago.

Brockman, B.K., Jones, M.A. and Becherer, R.C. (2012), "Customer orientation and performance in small firms: examining the moderating influence of risk-taking, innovativeness, and opportunity focus", Journal of Small Business Management, Vol. 50 No. 3, pp. 429-446.

Brown, J., Broderick, A.J. and Lee, N. (2007). Word of Mouth Communication Within Online Communities: Conceptualizing the Online Social Network. Journal of Interactive Marketing, Vol. 21 No. 3, pp. 2-20.

Burt, R. S. (1992), Structural hales: The social structure of competition, Harvard University Press, Cambridge, MA,

Burt, R.S. (1997), “The contingent value of social capital”, Administrative Science Ouarterly, Burt, R.S. (1997), “The contingent value of social capital, Vol.42 No.2, pp. 339-365.

Castells, M. (2001), The Internet galaxv: reflections on the Internet. business. and societv, Oxford University Press, New-York.

Chia, R. and Holt, R. (2006), "Strategy as practical coping: A Heideggerian perspective", Organization Studies, Vol. 27, No.5, pp. 635-655.

Chu, K.M. and Chan, H.C. (2009), "Community based innovation: its antecedents and its impact on innovation success", Internet Research, Vol.19 No.5, pp. 496 - 516.

Clemmensen, T. and Roese, K. (2010), “An overview of a decade of journal publications about culture and human-computer interaction (HCI)", IFIP Advances in Information and Communication Technology, Vol. 316, pp. 98-112. 
Cohen, A. K. (1999), “The sociology of the deviant act: Anomie theory and beyond”, in S. H. Traub and C. B. Little (Eds.), Theories of deviance, Thompson Wadsworth, Belmond, CA, pp. $158-170$.

Coleman, J. (1988), "Social capital in the creation of human capital", American Journal of Sociology, Vol. 94 Supplement, pp.95-120.

Collinson, D. (1994),"Strategies of resistance: Power, knowledge and subjectivity in the workplace", in Jermier, J.M., Knights, D. and Nord, W.R. (Eds), Resistance and Power in Organizations, Routledge New York, NY, pp. 25-68.

Compeau, D. R., Higgins, C. A. and Huff, S. (1999), "Social cognitive theory and individual reaction to computing technology: A longitudinal study", MIS Quarterly, Vol. 23 No. 2, pp. $145-158$.

Cova, B., Kozinets R.B. and Shankar, A. (2007), Consumer Tribes, Butterworth- Heinemann, London.

Curran, J.M., Meuter, M.L. and Suprenant, C.F. (2003), "Intentions to use self-service technologies: a confluence of multiple attitudes", Journal of Service Research, Vol. 5 No.3, pp. 209- 24.

Dacin, T., Goodstein, J. and Scott, W. R. (2002), "Institutional theory and institutional change: Introduction to the special research forum", Academy of Management Journal, Vol. 45 No.1, pp. 45-46.

Daniel, B. K. (2009), Social capital modeling in virtual communities: Bavesian belief network approaches, IGI Publishing, Hershey.

De Kervenoael R., Hallsworth, A.G., and Tang, D. (2014), “Singapore’s Online Retail Deviants: The case of Blogshops vs. traditional online shop", in Musso, F., and Druica, E,. Multi-Perspective Analysis of Retailer-Consumer Relationships, IGI Global Publishing, Hershey, pp. . 
De Kervenoael, R., Palmer, M. and Hallsworth, A. (2013)," From the outside in: Consumer anti-choice and policy implications in the mobile gaming market", Telecommunication Polick, Vol.37 No. (6/7), pp. 439-449.

Dekker, P., and Uslaner, E.M. (2001), Social Capital and Participation in Evervdav Life. Routledge, New York.

Denegri-Knott, J. (2006),'Consumers Behaving Badly: Deviation or Innovation? Power Struggles on the Web", Journal of Consumer Behaviour, Vol. 5 No. 1, pp. 82-94.

DiMaggio, P.J. (1998),'The new institutionalisms: Avenues of collaboration", Journal of Institutional and Theoretical Economics, Vol. 154 No.4, pp. 697-705.

Dotsika, F. and Patrick, K. (2013),"Collaborative KM for SMEs: A framework evaluation study", Information Technology \& People, Vol. 26 No. 4, pp. 368-382.

Fisher, A (2012), "Intrapreneurship", available at: http://management.fortune.cnn.com/2012/02/10/will-your-company-back-your-newbusiness-idea (accessed 10 February 2012).

Fleming, P. and Spicer, A. (2007), Contesting the Corporation, Cambridge University Press, Cambridge, UK.

Fleming, P. and Spicer, A. (2008), "Beyond power and resistance", Management Communication Quarterly, Vol. 21 No. 3, pp. 301-309.

Froehle, C.M. and Roth,A.V. ( 2004)," New measurement scales for evaluating perceptions of the technology-mediated customer service experience", Journal of Operations Management, Vol. 22 No. 1, pp. 1-21.

Galvin, T.L, Ventresca, M.J. and Hudson, B.A. (2005), “Contested Industry Dynamics. New directions in the study of legitimacy", International Studies of Management and Organization, Vol. 34 No. 4, pp. 57-84. 
Gazzoli, G., Hancer, M., Kim, BC. (2013), Explaining why employee-customer orientation influences customers' perceptions of the service encounter. Journal of Service Management, Vol 24 No 4 pp. 330-352.

Geertz, C. (1973), “Thick description: towards an interpretive theory of culture”, The Interpretation of Cultures, in Geertz, C. (Ed.), The interpretation of culture, Basic Books, New-York, pp.3-30.

Goodwin, L.D. and Goodwin, W.L. (1984), “Are validity and reliability relevant in qualitative evaluation research", Evaluation and the Health Professions, Vol. 7 No. 4, pp. 413-426.

Harris, L.C. (2000),'The organizational barriers to developing market orientation", Euronean Journal of Marketing, Vol. 34 No.5-6, pp. 354-373.

Holt, D. B. (2002),” Why Do Brands Cause Trouble? A Dialectical Theory of Consumer Culture and Branding”, Journal of Consumer Research, Vol. 29 No. 1, pp. 70-90.

Johnson, G., Langley, A., Melin, L. and Whittington, R. (2007), Strategv as Practice: Research Directions and Resource, Cambridge University Press, Cambridge, MA.

Johri, A. and Nair, S. (2011), "The role of design values in information system development for human benefit”, Information Technology \& People, Vol. 24 No. 3, pp. 281-302.

Jones, K. (2000), "The unsolicited diary as a qualitative research tool for advanced research capacity in the field of health and illness", Qualitative Health Research, Vol. 10 No. 4, pp. 55-567.

Kim, S. and Lee, H. (2010), "Factors affecting employee knowledge acquisition and application capabilities", Asia-Pacific Journal of Business Administration, Vol. 2 No. 2, pp. $133-152$.

Lafferty, B.A. and Hult, G.T. (1999), “A synthesis of contemporary market orientation perspectives", European Journal of Marketing, Vol. 35 No. 1/2, pp. 92-109. 
Levi, A. (2011)," How Apple (unintentionally) revolutionized corporate IT", available at:http://tech.fortune.cnn.com/2011/08/02/apples-unintentional-corporate-itrevolution/. (accessed 15 March 2012).

Lin, C.-H., Shih, H.-Y. and Sher, P.J. (2007), "Integrating technology readiness into technology acceptance: the tram model”, Psychology \& Marketing, Vol. 24 No. 7, pp. 641-57.

Lounsbury, V and Crumley, E.T. (2007), "New practice creation: An institutional perspective on innovation", Organization Studies, Vol. 28 No. 7, pp. 993-101.

Lusch, R. F., Vargo, S. L., and O'Brien, M. (2007), "Competing through service: Insights from service-dominant logic", Journal of Retailing, Vol. 83 No. 1, pp. 5-18.

Martin, J. (2002), Organizational Culture: Mapping the Terrain, Sage Publications, Thousand Oaks.

McLeod, C., O’Donohoe, S., and Townley, B., (2011), “Pot noodles, placements and peer regard: creative career trajectories and communities of practice in the British advertising industry", British. Journal of Management, Vol.22 No.1, pp.114-131.

Müller, S. D. and Nielsen, P. A. (2013), "Competing values in software process improvement: a study of cultural profiles”, Information Technology \& People, Vol. 26 No. 2, pp. 146-171,

Ndlela, L.T. and du Toit, A.S.A. (2001), "Establishing a knowledge management programme for competitive advantage in an enterprise", International Journal of Information Management, Vol 21 No. 2, pp. 151-65.

Neuman, W. L. (2006), Social research methods: Qualitative and quantitative approaches (6th ed.), Pearson Allyn and Bacon, MA, Boston. 
Nov, O., Ye, C. and Kumarr, N. (2012), “A social capital perspective on meta-knowledge contribution and social computing”, Decision Support Systems, Vol. 53 No.1, pp. 118126.

Orlikowski, W.J. (2000), "Using technology and constituting structures: A practice lens for studying technology in organizations", Organization Science, Vol. 11 No. 4, pp. 404428.

Penaloza, L. and Price, L.L (1993), "Consumer resistance: A conceptual overview", Advances in Consumer Research, Vol 20 No. 1, pp. 123-128.

Phillips, N., Sewell, G. and Jaynes, S. (2008), “Applying critical discourse analysis in strategic management research", Organizational Research Methods, Vol. 11 No. 4, pp. $770-789$.

Pile, V. and Keith, M. (1997), Geography of Resistance, Routledge, London, UK.

Poster, M. (1992), "The question of agency: de Certeau and the history of consumption", Diacritics, Vol. 22 No. 2, pp.94-107.

Prahalad, C.K. and Venkat. R. (2003), “The New Frontier of Experience Innovation”, MIT Sloan Management Review, Vol. 44 No. 4, pp. 12-18.

Punch, K (1998), Introduction to Social Research: Quantitative and Qualitative Approaches, Sage, London.

Ram, S. and Sheth, J.N. (1989),"Consumer resistance to innovations: The marketing problem and its solutions", Journal of Consumer Marketing, Vol. 6, No. 2, pp. 5-14.

Ratten, V. (2009), "Adoption of technological innovations in the m-commerce industry", International Journal of Technology marketing, Vol. 4 No. 4, pp. 355-367.

Reychav, I. and Weisberg, J. (2000), "Going beyond technology: Knowledge sharing as a tool for enhancing customer-oriented attitudes", International Journal of Information Management, Vol. 29 No.5, pp. 353-361. 
Richie, J. and Spencer, L. (1994), "Oualitative data analvsis for applied policv research", in Bryman, A. and Burgess, R. (Eds), Analysing Qualitative Data, Routledge, London, pp. 173-194.

Robert, L. P., Dennis, A. R., and Ahuja, M. K. (2008), "Social capital and knowledge integration in digitally enabled teams", Information System research, Vol. 19 No.3, pp. 314-334.

Rogers, E. (1995), Diffusion of Innovations, Free Press, New-York.

Russel, D.W. and Russel, C.A. (2006), "Explicit and implicit catalysts of consumer resistance: The effects of animosity, cultural salience and country-of-origin on ubsequent choice", International Journal of Research Marketing, Vol. 23 No. 3, pp. $321-331$

Sharma, G. and Baoku, L. (2013), "Customer satisfaction in Web 2.0 and information technology Development”, Information Technology \& People, Vol. 26 No. 4, pp. 347367.

Silverman, D. (1993), Interpreting Qualitative Data. Methods for Analysing Talk, Text and Interaction, Sage Publications, Londres.

Snow, CE (1993) Families as social contexts for literacy development. In C.Daiute (ed.) The Development of Literacy Through Social Interaction, pp. 11-24. Jossey-Bass publishers, San Francisco.

Spicer, A. and Böhm, S. (2007),’Moving management: Theorizing struggles against the hegemony of management” Organization Studies, Vol. 28 No. 11, pp. 1667-1698.

Swidler, A. (1986), "Culture in Action: Symbols and Strategies", American Sociological Review, Vol. 51 No. 2, pp. 273-286. 
Tams, S. (2013), “Moving cultural information systems research toward maturity. A review of definitions of the culture construct”, Information Technology \& People, Vol. 26 No. 4, pp. 383-400.

Teo, T., Lim, G., and Fedric, S. (2007), "The adoption and diffusion of human resources information systems in Singapore", Asia Pacific Journal of Human Resources, Vol. 45 No. 1 , pp. $41-62$.

Tohidinia, Z. and Mosakhani, M. (2010). "Knowledge sharing behaviour and its predictors", Industrial Management and Data Systems, Vol. 110 No. 4, pp. 611 - 631.

Toral, I. (2013), The role of interoganisational tension and conflict in market creation practice, $\mathrm{PhD}$ thesis, Aston University, Birmingham.

Tymon, W.G. and Stumpf, S.A. (2003), "Social capital in the success of knowledge workers", Career Development International, Vol. 8 No. 1, pp. 12-20.

Walker, R. and Johnson, L. (2006), "Why Consumers Use and Do Not Use TechnologyEnabled Services”, Journal of Services Marketing, Vol. 20 No. 2, pp.125-35.

Wang, C., Harris, J. and Patterson, P., (2012), "Customer choice of self-service technology: the roles of situational influences and past experience", Journal of Service Management, Vol. 23 No. 1, pp. 54-78.

Wickramasinghe,V. and Weliwitigoda, P. (2011), "Benefits gained from dimensions of social capital: a study of software developers in Sri Lanka", Information Technology \& People, Vol. 24 No. 4, pp. 393-413.

Wu,W-P. (2008), "Dimensions of social capital and firm competitiveness improvement: the mediating role of information sharing", Journal of Management Studies, Vol. 45 No. 1, pp. 122-46. 
Yen, H.R., Gwinner, K.P. and Su, W. (2004), "The impact of customer participation and service expectation on locus attributions following service failure", International Journal of Service Industry Management, Vol. 15 No. 1, pp. 7-26.

Yu, D. and Hang, C. C. (2010), "A reflective review of disruptive innovation theory", International Journal of Management Reviews, Vol. 12 No. 4, pp. 435-452.

Zablah, A. R., Franke, G. R., Brown, T. J. and Bartholomew, D. E., (2012), "How and When Does Customer Orientation Influence Frontline Employee Job Outcomes? A MetaAnalytic Evaluation", Journal of Marketing, Vol. 76 No. 3 pp. 21-40.

Zakaria, N., Stanton, J.M. and Sarkar-Barney, S.T.M. (2003), "Designing and implementing culturally-sensitive IT applications: the interaction of culture values and privacy issues in the Middle East", Information Technology \& People, Vol. 16 No. 1, pp. 4975.

Zhou, T. (2011), “Understanding online community user participation: a social influence perspective", Internet Research, Vol. 21 No.1, pp.67-81. 


\section{Author biographies}

Ronan is a Marketing Lecturer at Sabanci University and network Lecturer at Aston University. His wider research interests lie under the umbrella of consumer behaviour and retailing, including the study of social, cultural, and technological transformations in how consumers (re)organize their lives and become producers of their experiences. His work has been published in Environment \& Planning A, World Development, The Service Industries Journal, Telecommunication Policy, International Journal of Retail \& Distribution Management.

Christophe is Assistant Professor at Kadir Has University in Competitive Intelligence and Management Information Systems. His researches focus on SMEs' Information Management \& Competitive Intelligence practices, Social media and Early Warning System. He has published in the Journal of Strategic Marketing, Communication Research Reports, Journal of Intelligence Studies in Business. He is President of the Internationally Accepted Marketing Standards Board.

Mark is a Professor of Marketing. His research has a distinctive research focus around the themes of market driving practice, institutions and innovation. The focus of his research questions has been on understanding the ways that market driving practice challenge and/or maintains the dominant institutional logic and industry boundaries in global value chains. This research activity has been published in a range of fields including the Journal of Economic Geography, European Journal of Marketing, International Business Review, European Management Journal, Journal of Marketing Management, Industrial Marketing Management, Journal of Strategic Marketing, International Marketing Review, Service Industries Journal, Studies in Higher Education, Telecommunications Policy and Environment and Planning A. 

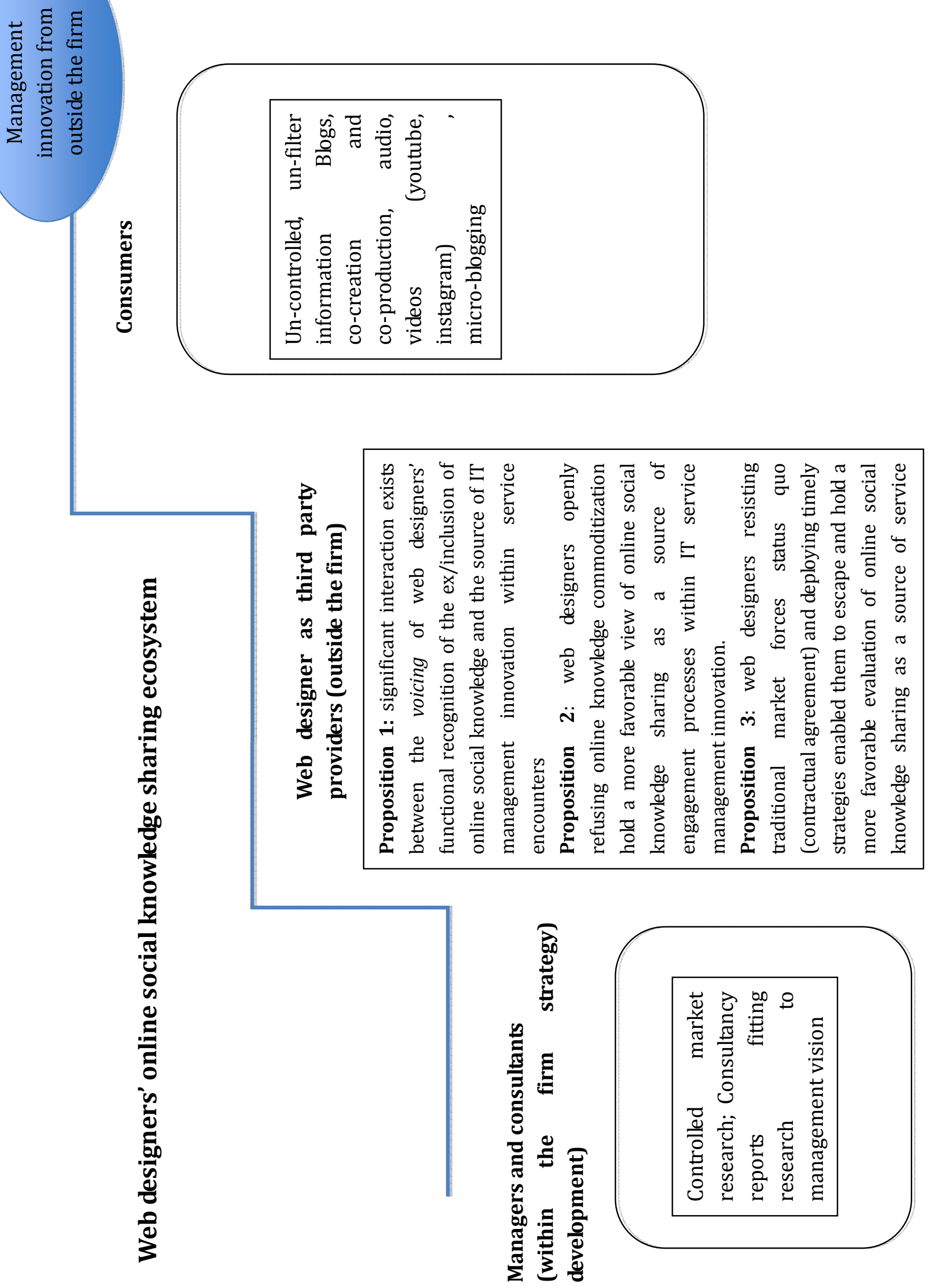

(c) Emerald Group Publishing Limited

This is a pre-print of a paper and is subject to change before publication. This pre-print is made available with the understanding that it will not be reproduced or stored in a retrieval system without the permission of Emerald Group Publishing Limited. 


\begin{tabular}{|c|c|c|c|c|c|c|}
\hline Name & Age & $\begin{array}{l}\text { Type of web } \\
\text { designers } \\
\text { regarding } \\
\text { social cues' } \\
\text { inclusion }\end{array}$ & $\begin{array}{l}\text { Education: } \\
\text { level and } \\
\text { type }\end{array}$ & $\begin{array}{l}\text { Time as } \\
\text { web } \\
\text { designer }\end{array}$ & $\begin{array}{l}\text { The } 5 \text { most } \\
\text { prestigious website } \\
\text { you designed or } \\
\text { helped in the } \\
\text { design? }\end{array}$ & $\begin{array}{c}\text { The } 5 \text { most influential } \\
\text { source of information in } \\
\text { your work that you read } \\
\text { regularly }\end{array}$ \\
\hline Kareen & $26-35$ & Progressive & $\begin{array}{l}\text { University. } \\
\text { School of } \\
\text { web } \\
\text { designers }\end{array}$ & 13 years & $\begin{array}{l}\text { Yahoo! Kelley Blue } \\
\text { Book, Nissan, Sea } \\
\text { Island, Playlist }\end{array}$ & $\begin{array}{l}\text { Engadget, Tech Crunch, } \\
\text { Gizmodo, IXDA, NNG }\end{array}$ \\
\hline Sheila & $36-45$ & Traditional & $\begin{array}{l}\text { University. } \\
\text { Autodidact } \\
\text { (scientific, } \\
\text { social } \\
\text { sciences) }\end{array}$ & 11 years & $\begin{array}{l}\text { MTV, VH1, The } \\
\text { Hawn Foundation, } \\
\text { PacSun, Dell }\end{array}$ & $\begin{array}{l}\text { Twitter eye-tracking } \\
\text { topics, UI Patterns } \\
\text { website, IxDA forums, } \\
\text { Linkedin forums }\end{array}$ \\
\hline Pablo & $36-45$ & Traditional & $\begin{array}{l}\text { University. } \\
\text { Other field }\end{array}$ & 14 years & Pfizer & $\begin{array}{c}\text { Jakob Nielsen, } \\
\text { Lynda,Adobe Flash } \\
\text { Documentation, Learning } \\
\text { Action Script 3, } \\
\text { Communication Arts }\end{array}$ \\
\hline Achille & $26-35$ & Progressive & $\begin{array}{l}\text { University. } \\
\text { Other field }\end{array}$ & 14 years & $\begin{array}{l}\text { Apple, Google, } \\
\text { Electronic Arts, } \\
\text { Charles Schwab, } \\
\text { Wells Fargo }\end{array}$ & $\begin{array}{c}\text { Technology Review, } \\
\text { Communication Arts, } \\
\text { Wired Magazine, Dwell, } \\
\text { Engaget }\end{array}$ \\
\hline Barrack & $26-35$ & Progressive & $\begin{array}{l}\text { University. } \\
\text { Other field }\end{array}$ & 7 years & $\begin{array}{c}\text { USA TODAY, } \\
\text { John Kerry } \\
\text { Presidential } \\
\text { Campaign, Noblis, } \\
\text { National Wildlife } \\
\text { Federation, } \\
\text { Pentagon. }\end{array}$ & $\begin{array}{c}\text { Google's designs, } \\
\text { Favourite Website Awards, } \\
\text { blogs, Web by Awards, } \\
\text { Human Factors. }\end{array}$ \\
\hline Rita & $36-45$ & Traditional & $\begin{array}{l}\text { University. } \\
\text { Other field }\end{array}$ & 13 years & $\begin{array}{l}\text { 99Fish, Fur Is } \\
\text { Dead, All About } \\
\text { Animals. Fishing } \\
\text { Hurts, Caring } \\
\text { Consumer }\end{array}$ & $\begin{array}{l}\text { Communication Arts, A } \\
\text { List Apart, My Fonts, } \\
\text { Wired, AIGA }\end{array}$ \\
\hline Louis & $18-25$ & Progressive & $\begin{array}{l}\text { University. } \\
\text { Other field }\end{array}$ & 7 years & $\begin{array}{l}\text { bigspaceship- rga- } \\
\text { razorfish- first born } \\
\text { multimedia-hugeinc }\end{array}$ & $\begin{array}{c}\text { Smashing } \\
\text { Magazine, underconsiderat } \\
\text { ion, Mashable Mag, NY } \\
\text { Times, freelanceswitch }\end{array}$ \\
\hline John & $26-35$ & Progressive & $\begin{array}{l}\text { University. } \\
\text { Other field }\end{array}$ & 14 years & $\begin{array}{c}\text { McKinsey, Bank of } \\
\text { America, Light to } \\
\text { Unite, Sustiva Ad } \\
\text { Campaigns, Social } \\
\text { Retailing }\end{array}$ & $\begin{array}{l}\text { Techcrunch, mashable, } \\
\text { news, wired, slashdot }\end{array}$ \\
\hline Hillary & $46-55$ & Progressive & $\begin{array}{l}\text { Master. } \\
\text { Autodidact } \\
\text { (scientific, } \\
\text { social } \\
\text { sciences) }\end{array}$ & 9 years & $\begin{array}{c}\text { Freeze Frame } 4 \\
\text { Vets, Golgotha - } \\
\text { The Movie, Mobile } \\
\text { Medical Care. }\end{array}$ & $\begin{array}{l}\text { A List Apart, Smashing } \\
\text { Magazine, JoomBlogger, } \\
\text { The Best Of Joomla, and } \\
\text { Freelance Switch. }\end{array}$ \\
\hline Albert & $18-25$ & Traditional & $\begin{array}{l}\text { University. } \\
\text { Autodidact } \\
\text { (scientific, } \\
\text { social } \\
\text { sciences) }\end{array}$ & 14 years & & $\begin{array}{c}\text { A List Apart, NETTUTS, } \\
\text { Smashing Magazine, Six } \\
\text { Revisions, and Individual } \\
\text { Designer/Developer Blogs }\end{array}$ \\
\hline Jenny & $18-25$ & Traditional & $\begin{array}{l}\text { High school. } \\
\text { Autodidact } \\
\text { (scientific, } \\
\text { social } \\
\text { sciences) }\end{array}$ & 9 years & & $\begin{array}{l}\text { UXBooth, A List Apart, } \\
\text { Jakob Nielson's Alertbox, } \\
\text { Matt Mullenweg's blog, } \\
\text { and Deviant Art }\end{array}$ \\
\hline
\end{tabular}




\begin{tabular}{|c|c|c|c|c|c|c|}
\hline Bob & $26-35$ & Progressive & $\begin{array}{l}\text { University. } \\
\text { Other field }\end{array}$ & 5 years & $\begin{array}{l}\text { Computerworld, } \\
\text { Network world, IT } \\
\text { world, Infoworld, } \\
\text { CIO }\end{array}$ & $\begin{array}{c}\text { Smashing Magazine, } \\
\text { Boxes and Arrows, } \\
\text { Mashable, Behance, A List } \\
\text { Apart }\end{array}$ \\
\hline Tom & $18-25$ & Traditional & $\begin{array}{l}\text { University. } \\
\text { Other field }\end{array}$ & 4 years & $\begin{array}{c}\text { Specialk, } \\
\text { leggomyeggo, } \\
\text { whirlpoolatlowes, } \\
\text { maytaghomedepot } \\
\text { wagworld }\end{array}$ & $\begin{array}{l}\text { Smashing Magazine, } 24 \\
\text { ways, blog jquery, } \\
\text { cssremix styleboost }\end{array}$ \\
\hline Thor & $36-45$ & Progressive & $\begin{array}{l}\text { Master. } \\
\text { Communicat } \\
\text { ion } \\
\end{array}$ & 15 years & $\begin{array}{l}\text { Marriott, Pearson } \\
\text { Education, AOL, } \\
\text { Bank of America }\end{array}$ & $\begin{array}{l}\text { Smashing Magazine, } \\
\text { Mashable, blogs }\end{array}$ \\
\hline Tim & $26-35$ & Progressive & $\begin{array}{l}\text { High school. } \\
\text { School of } \\
\text { web } \\
\text { designers }\end{array}$ & 14 years & $\begin{array}{l}\text { Budweiser, } \\
\text { Budlight, Zenith }\end{array}$ & $\begin{array}{l}\text { Mashable, TechCrunch, } \\
\text { HuffingtonPost, } \\
\text { Webmonkey, }\end{array}$ \\
\hline Rafael & $26-35$ & Progressive & $\begin{array}{l}\text { University. } \\
\text { Autodidact } \\
\text { (scientific, } \\
\text { social } \\
\text { sciences) }\end{array}$ & 5 years & $\begin{array}{l}\text { pmagrappa, ibbeta, } \\
\text { ilcharlie, playdom }\end{array}$ & $\begin{array}{c}\text { Boag World, Twitter - } \\
\text { following names such as } \\
\text { @BoagWorld } \\
@ \text { RyanCarson } \\
\text { @ElliotJayStocks and } \\
\text { @Malarkey, Think } \\
\text { Vitamin Radio podcast, } \\
\text { Smashing Magazine }\end{array}$ \\
\hline Bruce & $46-55$ & Progressive & Ph.D. IT & 12 years & I2 TV, I Bongo & $\begin{array}{l}\text { LightReading, CED,Media } \\
\text { Post,B2B }\end{array}$ \\
\hline Yoram & $26-35$ & Progressive & $\begin{array}{l}\text { University, } \\
\text { IT }\end{array}$ & 5 years & $\begin{array}{l}\text { Mindteck, Passhe, } \\
\text { Poslovni-savjetnik }\end{array}$ & $\begin{array}{c}\text { Microsoft, codeplex, } \\
\text { dotnetnuke, infragistics }\end{array}$ \\
\hline Way & $26-35$ & Progressive & Master. IT & 12 years & $\begin{array}{l}\text { Akron University, } \\
\text { Kipru, Interca, } \\
\text { Brandon Campus, } \\
\text { kizilkayalar }\end{array}$ & $\begin{array}{c}\text { Google search for } \\
\text { Learning and Inspiration, } \\
\text { Wikipedia, Web sites I } \\
\text { visit randomly } \\
\text { (Inspiration), Academic } \\
\text { Papers (Information) } \\
\end{array}$ \\
\hline Selena & $36-45$ & Traditional & $\begin{array}{l}\text { University, } \\
\text { communicati } \\
\text { on }\end{array}$ & 6 years & $\begin{array}{l}\text { Sarah Jones, Brian } \\
\text { Gallagher, } \\
\text { Kopplin's Coffee, } \\
\text { Crash+Sues, Sauce } \\
\text { Spirits \& Sound } \\
\end{array}$ & $\begin{array}{c}\text { Design Observer, A List } \\
\text { Apart, Smashing } \\
\text { Magazine, Wired, Mashabl } \\
\text { e }\end{array}$ \\
\hline Bill & $36-45$ & Traditional & $\begin{array}{l}\text { University. } \\
\text { Communicat } \\
\text { ion }\end{array}$ & 13 years & $\begin{array}{c}\text { Leslie the Realtor, } \\
\text { Master clean, WEA } \\
\text { Trust Member } \\
\text { Benefits, WSUM } \\
\text { 91.7FM Student } \\
\text { Radio, Flyover } \\
\text { Country }\end{array}$ & $\begin{array}{l}\text { Expression Engine CMS } \\
\text { community site and } \\
\text { forums, site point, CSS } \\
\text { beauty and W3C sites }\end{array}$ \\
\hline
\end{tabular}

Table 1. Respondents' profile 


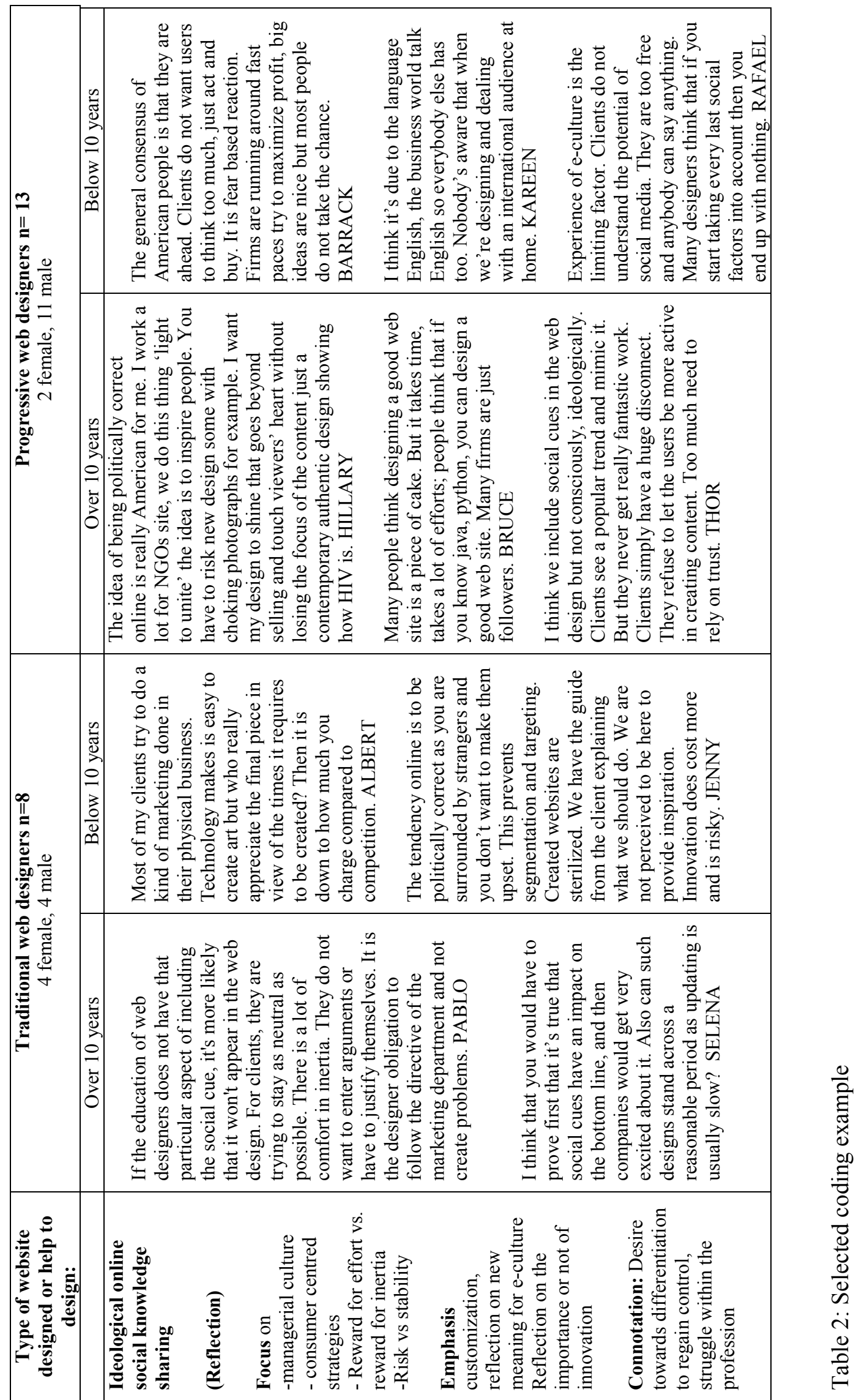

(c) Emerald Group Publishing Limited

This is a pre-print of a paper and is subject to change before publication. This pre-print is made available with the understanding that it will not be reproduced or stored in a retrieval system without the permission of Emerald Group Publishing Limited. 